\title{
Vanadium speciation by chromatographic separation of V(IV) and $V(V)$ in acidic solution followed by ICP-OES determination
}

\author{
Mingsong Hu and PP Coetzee* \\ Department of Chemistry, University of Johannesburg, JHB, South Africa
}

\begin{abstract}
A new method for vanadium speciation has been developed. The method is based on chromatographic separation of vanadium(IV) and vanadium(V) in acidic medium followed by the determination with ICP-OES. Vanadium species exist in acidic solution $(\mathrm{pH}<3)$ as $\mathrm{VO}^{2+}$ for vanadium $(\mathrm{IV})$ and $\mathrm{VO}_{2}^{+}$for vanadium $(\mathrm{V})$. The two vanadium species were chromatographically separated using a cation exchange column, Dionex IonPack CG10, and eluant $\left(120 \mathrm{mmol} / \ell \mathrm{H}_{2} \mathrm{SO}_{4}\right)$ at a flow rate of $1.5 \mathrm{~m} \ell / \mathrm{min}$. The detection limits for vanadium(IV) and vanadium(V) are $40 \mu \mathrm{g} / \ell$ and $30 \mu \mathrm{g} / \ell$, respectively. Among common anions, only nitrite, $\mathrm{NO}_{2}{ }^{-}$which may act as oxidant for vanadium(IV) and reductant for vanadium(V) can cause interference. Interference from common cations has not been observed for concentration levels not exceeding $40 \mathrm{mg} / \ell$. The developed method has been successfully applied to the determination of vanadium(IV) and vanadium(V) in synthetic and minerals processing samples.
\end{abstract}

Keywords: vanadium speciation, chromatography, ICP-OES, cation exchange

\section{Introduction}

Vanadium plays an important part in the analytical, biological, and environmental fields due to its dual character. Its toxicity is slightly less than that of lead, cadmium, and mercury at trace level concentrations (Wuilloud et al., 2000) but it also has beneficial biochemical functions, such as insulin-like and anti-carcinogenic characteristics (De Cremer et al., 2002). Therefore, the determination of vanadium in the samples from polluted areas and in nutrition studies has received much attention. Moreover, the toxicity of the two most stable vanadium oxidation states, i.e. vanadium(IV) and vanadium(V) is different, with the +5 oxidation state being more toxic. In biological systems, it has been proved that vanadium $(\mathrm{V})$ is a strong inhibitor of the Na- and Kadenosinetriphosphatase (ATPase) enzyme while vanadium(IV) is weak (Minelli. et al., 2000). In the industrial field, one of the important roles of vanadium is its catalytic property in manufacturing processes, such as the contact process for the manufacture of sulphuric acid, in which $\mathrm{V}_{2} \mathrm{O}_{5}$ has a catalytic function and is reduced to vanadium(IV), which does not function as the catalyst. Therefore, the determination of both vanadium species rather than the total vanadium(V) is important when correct evaluation of its toxicity and the health risks to humans as well as its functions in biological or industrial systems are required.

Inductively coupled plasma mass spectrometry (ICP-MS) (Garcia-Sanchez et al., 2004), spectrophotometry (Amin, 2003), spectrofluorometry (Gao et al., 2002), inductively coupled plasma optical emission spectrometry (ICP-OES) (Wuilloud et al., 2000; Wuilloud et al., 2002), catalytic (Okamura et al., 2001; Shiobara et al., 1999) and electrochemical (Jen et al., 1997) methods have been successfully applied for the determination of vanadium in environmental, industrial, and biological samples. Most earlier methods were focused on

\footnotetext{
* To whom all correspondence should be addressed.

용 +27 11 489-2558; fax: +27 11 489-2819;

e-mail: ppcoetzee@uj.ac.za

Received 5 December 2006; accepted in revised form 27 February 2007.
}

determining one of the two vanadium species, i.e. the most stable vanadium(V). During the past decade, however, interest has shifted from the determination of total vanadium to the measurement of the two stable vanadium species. EDTA (ethylenediaminetetraacetic acid) has been widely used for vanadium speciation because it forms stable complexes with the two vanadium species allowing chromatographic separation. Reversed-phase liquid chromatography with a C8 column has been selected as the separation system for vanadium(IV) and vanadium(V) by using a tertiary eluant containing EDTA by several researchers (Colina et al., 2005; Wann and Jiang , 1997). EDTA was also used as a trapping agent for both vanadium(IV) and vanadium(V) by Minelli et al.(2000) for vanadium speciation in natural water. Ahmed and Banoo (Ahmed and Banoo, 1999) have developed a twostep method for vanadium speciation. A mixture of the two species was first masked by tartrate and then 1,5-diphenylcarbohydrazide (DPCH) was added to form a red-violet chelate of vanadium(V). The chelate was measured for the determination of vanadium(V) concentration. Vanadium(IV) concentration was obtained by the subtraction of the vanadium(V) concentration from the total vanadium concentration. Another similar two-step method has been proposed by Filik et al. (2004) by using CDTA (1,2-cyclohexylenedinitrilo)tetr aacetic acid) as masking reagent for V(IV) instead of DPCH. Vanadium(V) was measured after the complexation with PAR (4-(2-pyridylazo)resorcinol), total vanadium concentration was obtained by the same method after the oxidation of vanadium(IV) to vanadium(V). The difference between the total vanadium concentration and the vanadium(V) concentration was the concentration of vanadium(IV). The two vanadium EDTA-complexes can be separated by a Dionex anion exchange column (Coetzee et al., 2002) or by a fused-silica capillary column modified with hexadecyltrimethylammonium bromide (Jen et al., 1997). A two-column separation of vanadium(IV) and vanadium(V) in acidic solution followed by catalytic detection (Okamura et al., 2001) has been developed. One column loaded with an acetylacetone-immobilised resin was used to collect vanadium(V) at $\mathrm{pH}$ 2.2-3.8 while 
another column loaded with an 8-quinolinole-immobilised resin was used to retain vanadium (IV). The retained two species can be successively eluted by diluted hydrochloric acid.

It was clear from the literature study that almost all developed methods for vanadium speciation are limited to separate the two vanadium species as their chelating complexes. No methods are reported where the two vanadium species are separated in the physico-chemical form in which they occur in the sample. Vanadium(V) is the most stable species but vanadium(IV) is easily oxidised to vanadium(V) in high $\mathrm{pH}$ value solutions. It can, however, be stable for months at low $\mathrm{pH}$ value. In the waste fluid from plants in which vanadium compounds have been used as catalysts the $\mathrm{pH}$ is often acidic. The two vanadium species may therefore co-exist in these fluids. In the analyses of vanadium in solid samples, acids are frequently used as the extractants, causing the extracts to support both vanadium(IV) and vanadium(V) in their physico-chemical forms. In view of these facts, it was considered necessary to develop a new method to directly separate and determine both vanadium species in the chemical forms in which they exist in acidic solutions. The purpose of this work was therefore to develop a fast and effective method based on cation exchange ion chromatography coupled with ICP-OES for the direct vanadium speciation analysis in the acidic media.

\section{Experimental}

\section{Reagents and water}

$1000 \mathrm{mg} / \ell$ vanadium(IV) and $1000 \mathrm{mg} / \ell$ vanadium(V) stock solutions were prepared by dissolving a certain amount of $\mathrm{VOSO}_{4} \cdot 5 \mathrm{H}_{2} \mathrm{O}$ (Merck, Germany) and $\mathrm{NH}_{4} \mathrm{VO}_{3}$ (Aldrich Chemical Company Inc., USA) in $20 \mathrm{mmol} / \ell \mathrm{H}_{2} \mathrm{SO}_{4}$, respectively. $4000 \mathrm{mmol} / \ell \mathrm{H}_{2} \mathrm{SO}_{4}$ stock solution was prepared from $98 \%$ $\mathrm{H}_{2} \mathrm{SO}_{4}$ (Promark Chemicals, Batch No. BX090904, South Africa) in deionised water and then filtered through a $0.45 \mu \mathrm{m}$ membrane filter. Filtered deionised water was obtained from a Milli-Q water purification system (Milllipore) with a resistivity of $18.2 \mathrm{M} \Omega . \mathrm{cm}$. All reagents were of analytical grade (AR). The samples or standards were prepared by properly diluting the stock solutions with deionised water.

The preparation of vanadium(V) stock solution was done by taking proper precautions. The vanadium(V) solution cannot be prepared by dissolving ammonium meta-vanadate in 20 $\mathrm{mmol} / \ell$ sulphuric acid because at low $\mathrm{pH}(\mathrm{pH}<2)$ and high concentrations, vanadate rapidly converts to vanadium pentoxide which has very low solubility in acidic solution and precipitates. Vanadium(V) stock solution was therefore prepared by dissolving ammonium meta-vanadate in hot water using sonication to increase the rate of dissolution. After complete dissolution of the compound, a measured amount of $4000 \mathrm{mmol} / \ell$ sulphuric acid was added to the solution drop by drop to make the final solution contain $20 \mathrm{mmol} / \ell$ sulphuric acid.

\section{Instrumentation}

Separation was performed using a Dionex high-performance liquid chromatography (HPLC) system with a Dionex IonPack CG10 column at a flow rate of $1.5 \mathrm{~m} \ell / \mathrm{min}$ and $120 \mathrm{mmol} / \ell \mathrm{H}_{2} \mathrm{SO}_{4}$ as eluant. The sample size for a single injection was $50 \mu \ell$. The determination was conducted on an ICP-OES (Varian Liberty 110, Australia) equipped with a V-groove nebuliser. The operating conditions for ICP-OES are shown in Table 1.

\begin{tabular}{|l|l|}
\hline \multicolumn{2}{|c|}{ TABLE 1 } \\
The ICP-OES operating conditions \\
\hline Determination wavelength & $309.311 \mathrm{~nm}$ \\
\hline Viewing height & $8 \mathrm{~mm}$ \\
\hline Search window & $0.040 \mathrm{~nm}$ \\
\hline Filter & 1 \\
\hline Order & 1 \\
\hline PMT & $650 \mathrm{~V}$ \\
\hline Power & $1.20 \mathrm{~kW}$ \\
\hline Plasma gas flow rate & $13.5 \ell / \mathrm{min}$ \\
\hline Auxiliary gas flow rate & $1.50 \ell / \mathrm{min}$ \\
\hline Pump speed & $30.0 \mathrm{r} / \mathrm{min}$ \\
\hline Nebuliser pressure & $150 \mathrm{kPa}$ \\
\hline
\end{tabular}

\section{Working principle}

In acidic solution, vanadium(IV) exists as the cationic form, $\mathrm{VO}^{2+}$. Although vanadium(V) exists as anionic vanadate or poly-vanadates at high $\mathrm{pH}$ value, it can be changed to the cationic dioxo-vanadium $(\mathrm{V})$ ion $\left(\mathrm{VO}_{2}^{+}\right)$at low $\mathrm{pH}$ conditions $(\mathrm{pH} 3$ or lower) according to the following equilibrium:

$$
\left[\mathrm{H}_{4} \mathrm{~V}_{10} \mathrm{O}_{28}\right]^{2-} \rightleftharpoons \mathrm{VO}_{2}^{+}
$$

If the $\mathrm{pH}$ value is controlled at lower than 3, the two vanadium species are cationic and can be separated by cation exchange columns. Vanadium(V) elutes first, followed by the vanadium(IV).

\section{Results and discussion}

\section{The stability of vanadium(IV)}

At low $\mathrm{pH}$ value ( $\mathrm{pH} 3$ or lower) and low concentration, vanadium(V) exists as the relatively stable dioxo-vanadium(V), $\mathrm{VO}_{2}{ }^{+}$. By contrast, vanadium(IV) is only stable at $\mathrm{pH} 2$ or lower. It is gradually oxidised at $\mathrm{pH} 5 \sim 6$ and rapidly oxidised to vanadium(V) by air at $\mathrm{pH} \geq 9$ (Bailar et al., 1973). In order to prevent the oxidation of vanadium(IV), vanadium(IV) solutions are prepared in $20 \mathrm{mmol} / \ell \mathrm{H}_{2} \mathrm{SO}_{4}(\mathrm{pH}<2)$. Experimental results show that, in $20 \mathrm{mmol} / \ell_{2} \mathrm{SO}_{4}$ solution, the oxidation of vanadium(IV) was not observed in three months. Therefore, all vanadium species, including vanadium(IV) and (V) are prepared in $20 \mathrm{mmol} / \ell \mathrm{H}_{2} \mathrm{SO}_{4}$ solution, in which they are all stable and cationic and ready for analysis.

\section{Optimisation of LC conditions}

\section{The choice of eluant}

To keep the stability of vanadium(IV), the eluant should be at low $\mathrm{pH}$ value $(<2)$ and non-oxidative. In order to obtain such a low $\mathrm{pH}$ value, only strong mineral acids may be suitable for the purpose. Among the common mineral acids, nitric acid is oxidative and cannot be used as the eluant. Of the two strong mineral acids, sulphuric acid and hydrochloric acid, the latter has a lower elution ability than that of sulphuric acid when their concentrations are the same. Therefore, sulphuric acid was chosen as the eluant. Table 2 shows the change in the retention time and resolution with the change in sulphuric acid concentration.

Results show that the concentration of sulphuric acid 


\begin{tabular}{|c|c|c|c|}
\hline \multicolumn{4}{|c|}{ TABLE 2} \\
$\begin{array}{c}\text { The change of retention time and resolution with } \\
\text { the change of sulphuric acid concentration } \\
\text { CG10 column. Flow rate: } \mathbf{1 . 5} \text { me/e }\end{array}$ \\
\hline $\begin{array}{c}\text { Concen- } \\
\text { tration } \\
\text { (mmol/l) }\end{array}$ & $\begin{array}{c}\text { V(V) } \\
\text { Retention time } \\
\text { (min) }\end{array}$ & $\begin{array}{c}\text { V(IV) } \\
\text { Retention } \\
\text { time (min) }\end{array}$ & Resolution \\
\hline 80 & 0.531 & 2.259 & 4.8 \\
\hline 100 & 0.512 & 1.638 & 3.6 \\
\hline 120 & 0.513 & 1.236 & 2.5 \\
\hline 140 & 0.479 & 1.052 & 2.1 \\
\hline 160 & 0.528 & 1.006 & 1.5 \\
\hline
\end{tabular}

only slightly affected the elution of vanadium(V) but seriously affected the elution of vanadium(IV). Vanadium(IV) could not be eluted within $10 \mathrm{~min}$ when $20 \mathrm{mmol} / \ell$ sulphuric acid was used as the eluant for a CG10 column. The two peaks were overlapping when $250 \mathrm{mmol} / \ell$ sulphuric acid was used while the retention times for vanadium(V) only changed from $0.667 \mathrm{~min}$ to $0.508 \mathrm{~min}$. Whether some multi-charged cations can affect the elution of the two species has been further examined experimentally. The common multi-charged cations, as well as a strong eluting ion, $\mathrm{Mg}^{2+}$ have been chosen for this experiment. $\mathrm{Mg}^{2+}$ added to a low concentration of sulphuric acid decreased the elution time for vanadium(IV) species, but caused high-emission backgrounds due to its emission line at $309.299 \mathrm{~nm}$, close to the vanadium emission line of $309.311 \mathrm{~nm}$. It also resulted in the broadening and overlapping of the peaks. Sulphuric acid without addition of $\mathrm{Mg}^{2+}$ was therefore chosen as eluant.

\section{The choice of a suitable column for the separation}

Two cation exchange columns were tested. The Dionex CG10 column produced a good separation for vanadium(IV) and vanadium(V) by using $120 \mathrm{mmol} / \ell \mathrm{H}_{2} \mathrm{SO}_{4}$ or $160 \mathrm{mmol} / \ell \mathrm{H}_{2} \mathrm{SO}_{4}$ as eluant at a flow rate of $1.5 \mathrm{ml} / \mathrm{min}$ (the resolution for the separation was larger than 1.5). The Dionex CG12A column with $120 \mathrm{mmol} / \ell \mathrm{H}_{2} \mathrm{SO}_{4}$ or $160 \mathrm{mmol} / \ell \mathrm{H}_{2} \mathrm{SO}_{4}$ as the eluant, however, caused partial overlapping of the peaks. Therefore, the CG10 column has been chosen for this study.

\section{Optimisation of the eluant concentration and flow rate}

As mentioned above, the concentration of sulphuric acid only slightly affected the elution of vanadium(V), which eluted first but seriously affected the elution of vanadium(IV). At the same flow rate, the higher the eluant concentration, the shorter the retention time for vanadium(IV) and the quicker the analysis. Experiment results given in Table 3 show that at the same con-

\section{TABLE 3}

The variation of peak parameters with the flow rate CG 10 column: Eluant: $120 \mathrm{mmol} / \mathrm{\ell} \mathrm{H}_{2} \mathrm{SO}_{4}$; injection size: 50 $\mu \ell$;sample: the mixture of $10 \mathrm{mg} / \ell \mathrm{V}(\mathrm{IV})$ and $10 \mathrm{mg} / \mathrm{\ell} \mathrm{V(V)}$

\begin{tabular}{|c|c|c|c|c|c|c|c|}
\hline \multirow{2}{*}{$\begin{array}{c}\text { Flow rate } \\
\text { (me/min) }\end{array}$} & \multicolumn{3}{|c|}{ Vanadium(V) } & \multicolumn{3}{c|}{ Vanadium(IV) } & \multirow{2}{*}{$\begin{array}{c}\text { Reso- } \\
\text { lution }\end{array}$} \\
\cline { 2 - 7 } & $\begin{array}{c}\text { (min) } \\
\text { low }\end{array}$ & $\begin{array}{c}\text { PW } \\
\text { (s) }\end{array}$ & PA & $\begin{array}{c}\text { RT } \\
\text { (min) }\end{array}$ & $\begin{array}{c}\text { PW } \\
\text { (s) }\end{array}$ & PA & \\
\hline 1.1 & 0.649 & 13.3 & 14306 & 1.608 & 14.6 & 13907 & 2.4 \\
1.3 & 0.576 & 10.3 & 14226 & 1.411 & 12.3 & 12590 & 2.6 \\
1.5 & 0.513 & 9.1 & 13016 & 1.236 & 11.2 & 11615 & 2.5 \\
1.7 & 0.467 & 7.7 & 12827 & 1.113 & 8.9 & 11393 & 2.7 \\
\hline
\end{tabular}

RT: retention time. $P W$ : peak width. PA: peak area. centration level, although high flow rate reduced both of the retention times for $\mathrm{V}(\mathrm{IV})$ and $\mathrm{V}(\mathrm{V})$, it also reduced the peak widths, making the resolution remain nearly unchanged. Peak areas were only slightly reduced with the increase in flow rate.

The results given in Table 3 show the expected decrease in retention time with increasing flow rate and the reduction in peak area. The overlapping of peaks at high flow rate has also been observed experimentally, especially for the measurement of the two species with high concentration. A medium flow rate of $1.5 \mathrm{~m} \ell / \ell$ was therefore chosen for analyses. The optimised IC conditions are summarised in Table 4.

\begin{tabular}{|l|l|}
\hline \multicolumn{2}{|c|}{ TABLE 4 } \\
The optimised IC operation conditions \\
\hline Separation column & CG10 \\
\hline Eluant & $120 \mathrm{mmol} / \ell \mathrm{H}_{2} \mathrm{SO}_{4}$ \\
\hline Flow rate & $1.5 \mathrm{~m} \ell / \ell$ \\
\hline Injection size & $50 \mu \ell$ \\
\hline
\end{tabular}

\section{Detection limits}

The detection limits for vanadium(IV) and vanadium(V) were $40 \mu \mathrm{g} / \ell$ and $30 \mu \mathrm{g} / \ell$, respectively. The quantitative detection limits, at which the two species can quantitatively be integrated by the software used, were $0.2 \mathrm{mg} / \ell$ and $0.1 \mathrm{mg} / \ell$; for vanadium(IV) and $\mathrm{V}(\mathrm{V})$, respectively. The detection limit of vanadium $(\mathrm{V})$ is lower than that of vanadium(IV) because vanadium(V) elutes first and the consequently narrower peak makes the integration easier and more accurate.

\section{Interference study}

\section{Anion interference}

The emission lines for non-metals are far away from the chosen emission line of vanadium, and spectral interferences from common anions can therefore be neglected. Anions may, however, cause chemical interference through chemical reactions, such as precipitation, redox reactions, and complexation. Precipitation could result not only in the loss of vanadium but also causes the blockage of the column. Redox reactions will change one vanadium species to another, reducing the reliability of the determination, while complexation of vanadium species causes changes in retention times because the charge and structure change.

The common anions, $\mathrm{F}^{-}, \mathrm{Br}, \mathrm{Cl}^{-}, \mathrm{NO}_{3}^{-}, \mathrm{NO}_{2}^{-}, \mathrm{PO}_{4}^{3-}, \mathrm{Ac}^{-}$, $\mathrm{C}_{2} \mathrm{O}_{4}{ }^{2-}$ have been studied. Neither precipitation nor complexation has been observed during the study at concentrations as high as $200 \mathrm{mg} / \ell$ for each anion, probably due to the low $\mathrm{pH}$ of the sample, at which the complexes and precipitates are not likely to form.

\section{Cation interferences}

Among cations, only magnesium at the emission line of $309.299 \mathrm{~nm}$ and chromium at the emission line of $309.349 \mathrm{~nm}$ may cause potential spectral interferences at the vanadium emission line of 309.311 $\mathrm{nm}$. The potential interference from chromium can be avoided by an appropriate narrowing of the search window. Interference from magnesium on vanadium(IV) may be serious when its concentration is high because of the proximity of its emission line and the retention 
of $\mathrm{Mg}^{2+}$ (1.559 min) which is close to that of $\mathrm{VO}^{2+}$ under the selected IC conditions. Table 5 lists the experimental results for the interference from magnesium.

\begin{tabular}{|l|l|}
\hline \multicolumn{2}{|c|}{ TABLE 5} \\
Interference from magnesium \\
\hline & V(IV) Peak area \\
\hline $4 \mathrm{mg} / \ell \mathrm{V}(\mathrm{IV})$ only & $8157 \pm 328$ (max: 8485$)$ \\
\hline $4 \mathrm{mg} / \ell \mathrm{V}(\mathrm{IV})$ with $10 \mathrm{mg} / \ell \mathrm{Mg}$ & $8750 \pm 328$ (min: 8422$)$ \\
\hline $4 \mathrm{mg} / \ell \mathrm{V}(\mathrm{IV})$ with $40 \mathrm{mg} / \ell \mathrm{Mg}$ & $8894 \pm 254$ (min: 8640$)$ \\
\hline
\end{tabular}

The results show that magnesium does cause some interference in the determination of vanadium(IV) when its concentration is as high as $40 \mathrm{mg} / \ell$. If the magnesium concentration in samples is higher than $40 \mathrm{mg} / \ell$, the interference from magnesium can be easily eliminated by changing the analytical line of vanadium from $309.311 \mathrm{~nm}$ to $310.230 \mathrm{~nm}$, at which magnesium can not give any interference to the determination of vanadium.

\section{Ratio interference}

The maximum concentration ratios of the vanadium species for quantitative determination are summarised in Table 6 . The $\mathrm{V}(\mathrm{V}) / \mathrm{V}(\mathrm{IV})$ ratio was obtained by fixing the $\mathrm{V}(\mathrm{IV})$ concentration at $1 \mathrm{mg} / \mathrm{L}$ but changing the concentration of $\mathrm{V}(\mathrm{V})$. The $\mathrm{V}(\mathrm{IV}) / \mathrm{V}(\mathrm{V})$ ratio was obtained by fixing the $\mathrm{V}(\mathrm{V})$ concentration at $1 \mathrm{mg} / \ell$ but changing the concentration of $\mathrm{V}(\mathrm{IV})$.

\begin{tabular}{|l|l|}
\hline \multicolumn{1}{|c|}{$\begin{array}{c}\text { TABLE } 6 \\
\text { The ratio of interference from the concentration } \\
\text { ratio of } \mathrm{V}(\mathrm{IV}) \text { and } \mathrm{V}(\mathrm{V})\end{array}$} \\
\hline Ratio & Conclusion \\
\hline $\mathrm{V}(\mathrm{V}) / \mathrm{V}(\mathrm{IV}) \leq 12$ & Quantitative results for both species \\
\hline $25>\mathrm{V}(\mathrm{V}) / \mathrm{V}(\mathrm{IV})>12$ & $\begin{array}{l}\text { Quantitative results for } \mathrm{V}(\mathrm{V}) \text { but } \\
\text { qualitative results for } \mathrm{V}(\mathrm{IV})\end{array}$ \\
\hline $\mathrm{V}(\mathrm{IV}) / \mathrm{V}(\mathrm{V}) \leq 8$ & Quantitative results for both species \\
\hline $20>\mathrm{V}(\mathrm{IV}) / \mathrm{V}(\mathrm{V})>8$ & $\begin{array}{l}\text { Quantitative results for } \mathrm{V}(\mathrm{V}) \text { but } \\
\text { qualitative results for } \mathrm{V}(\mathrm{IV})\end{array}$ \\
\hline
\end{tabular}

\section{Applications of the developed method}

\section{The determination of vanadium in synthetic samples}

The results of the determination of synthetic samples are shown in Table 7.

\begin{tabular}{|c|c|c|c|c|c|c|}
\hline \multicolumn{7}{|c|}{$\begin{array}{c}\text { TABLE } 7 \\
\text { The determination of vanadium in synthetic samples }\end{array}$} \\
\hline \multirow{2}{*}{$\begin{array}{l}\text { Sample } \\
\text { No }\end{array}$} & \multicolumn{3}{|c|}{$\mathrm{V}(\mathrm{V})$} & \multicolumn{3}{|l|}{ V(IV) } \\
\hline & $\begin{array}{l}\text { Known } \\
(\mathrm{mg} / \ell)\end{array}$ & $\begin{array}{l}\text { Measured } \\
(\mathrm{mg} / \mathrm{l})\end{array}$ & $\begin{array}{l}\text { Recovery } \\
\text { (\%) }\end{array}$ & $\begin{array}{l}\text { Known } \\
(\mathrm{mg} / \mathrm{l})\end{array}$ & $\begin{array}{l}\text { Measured } \\
(\mathrm{mg} / \mathrm{l})\end{array}$ & $\begin{array}{l}\text { Recovery } \\
\text { (\%) }\end{array}$ \\
\hline 1 & 0.1 & $0.13 \pm 0.02$ & 130 & 0.2 & $0.21 \pm 0.02$ & 105 \\
\hline 2 & 0.2 & $0.21 \pm 0.03$ & 105 & 0.4 & $0.44 \pm 0.03$ & 110 \\
\hline 3 & 0.4 & $0.37 \pm 0.10$ & 93 & 0.8 & $0.82 \pm 0.03$ & 102 \\
\hline 4 & 0.8 & $0.77 \pm 0.04$ & 96 & 2.0 & $2.01 \pm 0.01$ & 100 \\
\hline 5 & 2.0 & $2.01 \pm 0.04$ & 100 & 4.0 & $3.99 \pm 0.08$ & 99.8 \\
\hline 6 & 5.0 & $5.41 \pm 0.27$ & 108 & 8.0 & $7.90 \pm 0.42$ & 98.8 \\
\hline 7 & 10.0 & $10.40 \pm 0.16$ & 104 & 20.0 & $20.04 \pm 0.28$ & 100 \\
\hline
\end{tabular}

For the synthetic samples, the measured results show excellent consistency with the known concentration. The recovery for the synthetic samples ranges from $93 \%$ to $110 \%$ except for $0.1 \mathrm{mg} / \ell$ vanadium( $(\mathrm{V})$ where the recovery was $130 \%$. This is caused by the low concentration of vanadium(V) which is close to the quantitative detection limit of vanadium $(\mathrm{V})$ by this method.

\section{The determination of vanadium species in a minerals processing matrix}

A minerals processing sample, with unknown vanadium speciation, was obtained from GRD Minproc. The composition of the sample was as follows: $\mathrm{U}_{3} \mathrm{O}_{8}, 841 \mathrm{mg} / \ell$ (equivalent to about 713 $\mathrm{mg} / \ell$ uranium); $\mathrm{V}_{2} \mathrm{O}_{5}, 234 \mathrm{mg} / \ell$ (equivalent to about $131 \mathrm{mg} / \ell$ ); $\mathrm{CO}_{3}^{2-}, 20 \mathrm{~g} / \ell(\sim 333 \mathrm{mmol} / \ell) ; \mathrm{Cl}^{-}, 0.55 \mathrm{~g} / \ell(\sim 15 \mathrm{mmol} / \ell) ; \mathrm{SO}_{4}^{2-}$, $1.2 \mathrm{~g} / \ell(\sim 12.5 \mathrm{mmol} / \ell)$; and $\mathrm{pH}, \sim 10$. Pre-analyses of the sample were performed by ICP-OES before the speciation determination to check for any major element that could cause interference. More than 20 elements were measured. It was found that in addition to uranium, only sodium was present in the sample at high concentration levels of about $17 \mathrm{mg} / \ell$. The other elements, including the possible interfering element of magnesium, were present at trace level. The $\mathrm{pH}$ of the sample was 10.7. The total concentration of vanadium was determined by ICP-OES using the dilution (10x-100x- and $1000 \mathrm{x}$ dilution) and standard addition methods. The results are shown in Table 8.

\begin{tabular}{|l|l|}
\hline \multicolumn{1}{|c|}{ TABLE 8} \\
\multicolumn{1}{|c|}{$\begin{array}{c}\text { The measurement of total vanadium concentration } \\
\text { in the real sample }\end{array}$} \\
\hline $\begin{array}{l}\text { Methods used for the determina- } \\
\text { tion }\end{array}$ & $\begin{array}{l}\text { Total vanadium } \\
\text { concentration }(\mathbf{m g} / \mathbf{\ell})\end{array}$ \\
\hline 10 -time dilution of the sample & 19.43 \\
\hline 100 -time dilution of the sample & 1.98 \\
\hline 1000-time dilution of the sample & 0.21 \\
\hline standard addition (100-time dilution) & 1.96 \\
\hline
\end{tabular}

The dilution method and the standard addition method both gave consistent results for the total vanadium concentration confirming absence of matrix effects during the determination.

According to the measured $\mathrm{pH}$ value, the sample is in a matrix of strong alkalinity. Vanadium(IV) species in the strong alkaline solution would therefore be oxidised rapidly and the sample was not expected to contain measurable quantities of vanadium(IV).

For column separation the sample needed prior filtration to prevent column blockage. To check whether filtration could affect the vanadium concentration, an unfiltered $10 \mathrm{x}$ diluted sample and filtered 10x diluted sample were analysed by ICPOES. The determined results are listed in Table 9.

\begin{tabular}{|l|l|}
\hline \multicolumn{2}{|c|}{$\begin{array}{c}\text { TABLE } 9 \\
\text { The determination of total V in the } \\
\text { sample before and after filtration }\end{array}$} \\
\hline Sample & $\begin{array}{l}\text { Total vanadium } \\
\text { concentration } \\
\text { (mg/ } \mathbf{~})\end{array}$ \\
\hline $\begin{array}{l}\text { Unfiltered 10-time dilution } \\
\text { sample }\end{array}$ & $19.43 \pm 1.02$ \\
\hline $\begin{array}{l}\text { Filtered 10-time dilution } \\
\text { sample }\end{array}$ & $19.14 \pm 0.97$ \\
\hline
\end{tabular}


Because acidic samples $(\mathrm{pH}<3)$ are required for separation of the V species, the sample was acidified before analysis. To reduce matrix effects and to obtain the optimum separation of the two species, the sample was diluted $10 x$ to give a final concentration of around $20 \mathrm{mg} / \ell$. Too high concentrations may cause peak overlap. The sample preparation procedure was: $5 \mathrm{~m} \ell$ filtered original sample was transferred to a $50 \mathrm{~m} \ell$ volumetric flask, and then acidified and diluted with $0.5 \mathrm{~mol} / \ell$ sulphuric acid to the mark. The prepared sample had a $\mathrm{pH}$ range of between 1 and 2, where vanadium(IV) and vanadium(V) exist as $\mathrm{VO}^{2+}$ and $\mathrm{VO}_{2}^{+}$, respectively. $50 \mu \ell$ sample was injected into the CG10 column and the eluted vanadium species determined by ICP-OES. Vanadium(V) was measured at the concentration of $21.52 \pm 1.03 \mathrm{mg} / \ell$, but vanadium(IV) was not detectable. Vanadium(V) therefore accounts for the total vanadium concentration of $215.2 \pm 10.3$, which is consistent with the total vanadium concentration, as shown in Table 8.

To verify the measured result for the sample, the standard addition method was applied. The sample was diluted 100 times and spiked with different concentrations of vanadium species. The concentration of vanadium(V) was calculated as $2.26 \mathrm{mg} / \ell$ and the concentration of vanadium(IV) as 0.018 $\mathrm{mg} / \ell$, which is below the detection limit. The measured results for vanadium(IV) and vanadium(V) were therefore consistent with the previous determination.

To demonstrate the effectiveness of the proposed IC-ICPOES method to determine $\mathrm{V}$ species in mineral-processing samples, samples spiked with different concentration ratios of $\mathrm{V}(\mathrm{IV})$ and $\mathrm{V}(\mathrm{V})$ after 100x dilution, were analysed. The results are given in Table 10.

Excellent consistency between the spiked concentrations and measured results has been obtained by the method.

\section{Conclusion}

A new IC-ICP-OES method has been developed to separate and determine vanadium (IV) and vanadium(V) in the acidic medium. The method not only determines vanadium(IV) and vanadium(V) in acidic solution, but can also be used to separate vanadium species in alkaline solution after acidification of the sample. The method is fast and effective and almost interference-free. Only magnesium could interfere with the determination of vanadium(IV) when its concentration is higher than $40 \mathrm{mg} / \ell$. The successful determination of vanadium(IV) and vanadium(V) in synthetic samples and a minerals processing sample with a relatively complex matrix indicates the usefulness of this method.

\section{References}

AHMED MJ and BANOO S (1999) Spectrophotometric method for determination of vanadium and its application to industrial, environmental, biological and soil samples. Talanta 48 1085-1094

AMIN AS (2003) Solid-phase spectrophotometric determination of trace amounts of vanadium using 2,3-dichloro-6(3-carboxy-2hydroxynaphthylazo) quinoxaline. Spectrochim. Acta Part A $\mathbf{5 9}$ 1025-1033.

BAILAR JC, EMELEUS HJ, NYHOLM SR and TROTMAN-DICKENSON AF (1973) Comprehensive Inorganic Chemistry. Pergamon Press, Oxford, UK.

COETZEE PP, FISCHER JL and HU M (2002) The separation and simultaneous determination of $\mathrm{V}(\mathrm{IV})$ and $\mathrm{V}(\mathrm{V})$ species complexed with EDTA by IC-ICP-OES. Water SA 28 (1) 37-44.

COLINA M, GARDINER PHE, RIVAS Z and TRONCONE F (2005) Determination of vanadium species in sediment, mussel and fish muscle tissue samples by liquid chromatography-inductively coupled plasma-mass spectrometry. Anal. Chim. Acta. 538 107-115.

DE CREMER K, CORNELIS R, STRIJCKMANS K, DAMS R, LAMEIRE N and VANBOLDER R (2002) Fractionation of vanadium in urine of Wistar rats as a function of time after intraperitoneal injection. J. Inorg. Biochem. 90 71-77.

FILIK H, BERKER KI, BALKIS N and APAK R (2004) Simultaneous preconcentration of vanadium(V/IV) species with palmitoyl quinolin-8-ol bonded to amberlite XAD 2 and their separate spectrophotometric determination with 4-(2-pyridylazo)-resorcinol using CDTA as masking agent. Anal.Chim. Acta 518 173-179.

GAO J, ZHANG X, YANG W and KANG J (2002) Highly sensitive spectrofluorimetric kinetic determination of ultratrace amounts of vanadium $(\mathrm{V})$ based on the oxidation of 1,8-diaminonaphthalene by bromate. Anal. Chim. Acta 455 159-165.

GARCIA-SANCHEZ R, BETTMER J and EBDON L (2004) Development of a new method for the separation of vanadium species and chloride interference removal using modified silica capillaries-DINICP-MS. Microchem. J. 76 161-171.

JEN J, WU M and YANG TC (1997) Simultaneous determination of vanadium(IV) and vanadium(V) as EDTA complexes by capillary zone electrophoresis. Anal. Chim. Acta 339 251-257.

MINELLI L, VESCHETTI E, GIAMMANCO S, MANCINI G and OTTAVIANI M (2000) Vanadium in Italian waters: monitoring and speciation of V(IV) and V(V). Microchem. J. 67 83-90.

OKAMURA K, SUGIYAMA M, OBATA H, MARUO M, NAKAYAMA E and KARATANI H (2001) Automated determination of vanadium(IV) and (V) in natural waters based on chelating resin separation and catalytic detection with Bindschedler's green leuco base. Anal. Chim. Acta 443 143-151.

SHIOBARA T, TESHIMA N, KURIHARA M, NAKANO $S$ and KAWASHIMA T (1999) Catalytic flow injection determination of vanadium by oxidation of $N$-(3-sulfopropyl)-3,3',5,5'-tetramethylbenzidine using bromate. Talanta 49 1083-1089.

WANN C and JIANG S (1997) Determination of vanadium species in water samples by liquid chromatography-inductively coupled plasma mass spectrometry. Anal. Chim. Acta 357 211-218.

\begin{tabular}{|c|c|c|c|c|c|c|c|}
\hline \multicolumn{8}{|c|}{$\begin{array}{c}\text { TABLE } 10 \\
\text { Recoveries for } 100 x \text { diluted sample spiked with different concentration } \\
\text { ratios of } \mathrm{V}(\mathrm{IV}) \text { and } \mathrm{V}(\mathrm{V})\end{array}$} \\
\hline \multirow{2}{*}{$\begin{array}{c}\text { Sample } \\
\text { No }\end{array}$} & \multicolumn{3}{|c|}{$\mathrm{V}(\mathrm{IV})$} & \multicolumn{4}{|c|}{$\mathrm{V}(\mathrm{V})$} \\
\hline & $\begin{array}{c}\text { Spiked } \\
(\mathrm{mg} / \mathrm{l})\end{array}$ & $\begin{array}{l}\text { Measured } \\
(\mathrm{mg} / \mathrm{l})\end{array}$ & $\begin{array}{c}\text { Recovery } \\
\text { (\%) }\end{array}$ & $\begin{array}{c}\text { Spiked } \\
(\mathrm{mg} / \mathrm{l})\end{array}$ & \begin{tabular}{|l|} 
Total $^{*}$ \\
$(\mathrm{mg} / \mathrm{l})$
\end{tabular} & $\begin{array}{l}\text { Measured } \\
(\mathrm{mg} / \mathrm{l})\end{array}$ & $\begin{array}{c}\text { Recovery } \\
\text { (\%) }\end{array}$ \\
\hline 1 & 20 & $20.03 \pm 0.12$ & 100 & 0 & 2.15 & $2.03 \pm 0.07$ & 94 \\
\hline 2 & 3 & $2.76 \pm 0.32$ & 92 & 20 & 22.15 & $21.94 \pm 0.17$ & 99 \\
\hline 3 & 10 & $10.10 \pm 0.07$ & 101 & 10 & 12.15 & $12.20 \pm 0.10$ & 100 \\
\hline 4 & 5 & $5.25 \pm 0.37$ & 105 & 15 & 17.15 & $17.14 \pm 0.47$ & 100 \\
\hline 5 & 15 & $14.86 \pm 0.02$ & 99 & 5 & 7.15 & $7.13 \pm 0.20$ & 100 \\
\hline 6 & 0 & Undetectable & & 2 & 4.15 & $3.97 \pm 0.01$ & 96 \\
\hline
\end{tabular}

* Total concentration of $V(V)$ after spiking 
WUILLOUD GM, DE WUILLOUD JCA, WUILLOUD RG, SILVA MF, OLSINA RA and MARTINEZ LD (2002) Cloud point extraction of vanadium in parenteral solutions using a nonionic surfactant (PONPE 5.0) and determination by flow injection-inductively coupled plasma optical emission spectrometry. Talanta 58 619-627.

WUILLOUD RG, SALONIA JA, GASQUEZ JA, OLSINA RA and MARTINEZ LD (2000) On-line pre-concentration system for vanadium determination in drinking water using flow injection-induc- tively coupled plasma atomic emission spectrometry. Anal. Chim. Acta 420 73-79.

WUILLOUD RG, SALONIA JA, OLSINA RA and MARTINEZ LD (2000) Determination of vanadium (V) in drinking water by flow injection and pre-concentration in a knotted reactor by inductively coupled plasma optical emission spectrometry with ultrasonic nebulization. Spectrochim. Acta part B 55 671-680. 